\title{
Synergistic Excited State involved Catalytic Reduction of (NH3-trz)[Fe(dipic)2] Complex by SnO2/TiO2 Nanocomposite
}

\section{Venkatesh D}

Pondicherry University

Pavalamalar S

Pondicherry University

\section{Silambarasan $\mathbf{R}$}

Pondicherry University

Anbalagan K ( $\nabla$ nmpcrg@gmail.com )

Pondicherry University School of Physical Chemical and Applied Sciences

\section{Research Article}

Keywords: (NH3-trz)[Fe(dipic)2], SnO2/TiO2 nanocomposites, adsorption, photoreduction, Hydroxy radical

Posted Date: February 1st, 2022

DOI: https://doi.org/10.21203/rs.3.rs-1192906/v2

License: (9) This work is licensed under a Creative Commons Attribution 4.0 International License. Read Full License 


\title{
Synergistic Excited State involved Catalytic Reduction of $\left(\mathrm{NH}_{3}-\mathrm{trz}\right)[\mathrm{Fe} \text { (dipic) })_{2}$ Complex
}

\section{by $\mathrm{SnO}_{2} / \mathrm{TiO}_{2}$ Nanocomposite}

\author{
D. Venkatesh, S. Pavalamalar, R. Silambarasan, and K. Anbalagan* \\ Department of Chemistry, Pondicherry University, Pondicherry 605014, India \\ E-mail:nmpcrg@gmail.com; Tel: +914132654509
}

\section{Graphical abstract}

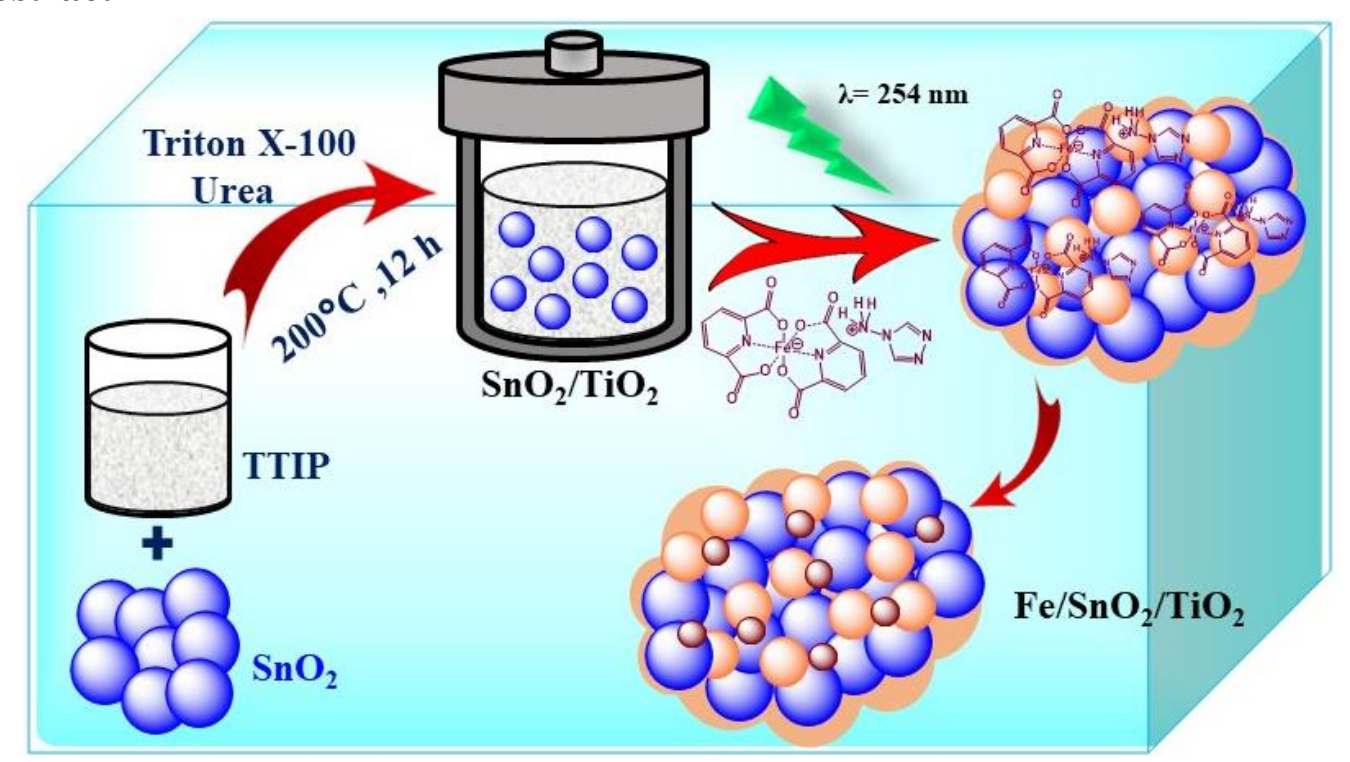

\section{Abstract}

The photocatalytic activity of well-fabricated, economical $\mathrm{SnO}_{2} / \mathrm{TiO}_{2}$ nanocomposite synthesized via hydrothermal route was validated using the $\left(\mathrm{NH}_{3}-\mathrm{trz}\right)\left[\mathrm{Fe}(\mathrm{dipic})_{2}\right]$ complex under ultra-violet illumination. The structural features of $\left(\mathrm{NH}_{3}-\mathrm{trz}\right)\left[\mathrm{Fe}(\mathrm{dipic})_{2}\right]$ complex was explored in detail. The catalysts were systematically examined with XRD, SEM, FT-IR UVvis, PL, micro-Raman, VSM, AFM, HRTEM. The photoreactivity of the model compound $\left(\mathrm{NH}_{3}\right.$-trz) $\left[\mathrm{Fe}(\text { dipic })_{2}\right]$ in water/binary solvent systems was investigated. The rate of photoreaction $(k)$ of nanocomposite $\left(0.1432 \mathrm{sec}^{-1}\right)$ is higher than the $\mathrm{SnO}_{2}\left(0.0373 \mathrm{sec}^{-1}\right)$ and $\mathrm{TiO}_{2}\left(0.1422 \mathrm{sec}^{-1}\right)$ in $\mathrm{H}_{2} \mathrm{O}: \mathrm{Pr}^{\mathrm{i}} \mathrm{OH}(70: 30 \%)$ than the rest of the solvents system. The pathways, mechanistic feature of accumulated reactive species on nanocomposite to induce adherent $\left[\mathrm{Fe}(\text { dipic })_{2}\right]^{-}$anion and photo-reductive products were studied. The generation of hydroxyl radical on the surface of each catalyst can be identified as 7-hydroxycoumarin and discussed

Keywords: $\left(\mathrm{NH}_{3}\right.$-trz) $\left[\mathrm{Fe}(\text { dipic })_{2}\right], \mathrm{SnO}_{2} / \mathrm{TiO}_{2}$ nanocomposites, adsorption, photoreduction, Hydroxy radical.

\section{Introduction}

In the past years, nanoscale heterostructures have been rapidly developed through research objective due to their favorable performance in various fields. The impacts are more obvious and precise in high-technology applications and the dimension dependence of nanoparticles brings novel electronic, optical, magnetic, and mechanical properties [1-4]. Research 
investigations combined that the construction of semiconductor heterostructures proved to be an excellent method for improving the photosynthetic function of a material. [5]. More formulations have been emphasized on hybrid heterostructure systems in recent years by coupling two/more metal oxides and the resulting new nanocomposites exhibit high photocatalytic reactivity compared with bare components [6-8]. Tin dioxide $\left(\mathrm{SnO}_{2}\right)$ is one of the acceptable $n$-type semiconductors with chemical and thermal stability (wide bandgap $=3.6$ $\mathrm{eV}$ at $300 \mathrm{~K}$ ) and it was used in transparent conductive electrodes, electronics, solar cells, energy storage, gas sensors, and photocatalysis $[9,10]$. Tin oxide is a good electron acceptor comparing anatase $\mathrm{TiO}_{2}$ (wide bandgap $=3.2 \mathrm{eV}$ at $300 \mathrm{~K}$ ) photocatalyst because $\mathrm{SnO}_{2}$ has a more positive conduction band edge and makes it a suitable candidate for the preparation of heterostructure [11,12]. It is worthy enough to associate $\mathrm{SnO}_{2}$ with $\mathrm{TiO}_{2}$ to obtain a unique heterostructure to achieve the synergistic effect between the two semiconductors. This modifies the electronic states of the composite, allows the transfer of photogenerated charge carriers to be switched between the two semiconductors, promotes electron/hole pair separation, and changes the lifetime of the carrier. Nanocomposite $\mathrm{SnO}_{2} / \mathrm{TiO}_{2}$ engineering using $\mathrm{SnO}_{2}$ with $\mathrm{TiO}_{2}$ becomes the anticipated best material from the point of matching bandgap, low in toxicity, good durability, high stability, promising in the separation of photogenerated electrons/holes, and results in highly efficient photocatalyst [13,14]. It is reasonable to exploit the photocatalytic efficiency of $\mathrm{SnO}_{2} / \mathrm{TiO}_{2}$ nanocomposite, the effect would be higher than that of individual $\mathrm{SnO}_{2}$ and $\mathrm{TiO}_{2}$ nanoparticles. Second, synthesis of this nanocomposite with a tunable and uniform composition comprising a tight interface [15-17]. The hybrid formation of $\mathrm{TiO}_{2}$ with $\mathrm{SnO}_{2}$ modifies the electronic structure and can be used to control and enhance the surface chemical and physical properties of $\mathrm{SnO}_{2} / \mathrm{TiO}_{2}$ nanocomposites [18-20]. The immobilizing of nanocomposite with the synthesized coordination compound can be considered as a good way for additional processes such as photocatalyst recovery and recycling $[21,22]$. Kinetically labile, high spin, hexacoordinated iron(III) complex shows enormous aspects in photophysics and photochemistry [23]. Transition metal complexes with nitrogen donor can provide versatile properties such as limited steric hindrance, structural lability, and sensitivity to surface platforms as functional materials [24-26]. The spin cross over (SCO) is possible in $d^{5}$ system of the metal complex at the metal centre. Due to external stimuli such as irradiating light source, temperature and pressure changes, it affects the spin states to switch over between high spin state to low spin state or vice versa. This induces notable modifications in the structural, vibrational, magnetic, or optical properties of the complex [27]. In the present piece of investigation, we report for the first time to our knowledge the controlled synthesis of 
$\mathrm{SnO}_{2} / \mathrm{TiO}_{2}$ nanocomposite photocatalyst coupled with an iron(III) complex to induce photoreduction activities probed under UV illumination.

\section{Experimental Section}

\subsection{Synthesis of 4-amino-4H-1,2,4-trizol-4-ium-bis(pyridine-2,6-dicarboxylato) ferrate(III) Complex}

$\left(\mathrm{NH}_{3}\right.$-trz $)\left[\mathrm{Fe}(\text { dipic })_{2}\right]$ was prepared with some altered methodology from the published procedure [28]. Bis(pyridine-2,6-dicarboxylato)ferrate(III) anion for the present study was prepared using the starting material anhydrous $\mathrm{FeCl}_{3}(0.33 \mathrm{mmol})$ and 2,6-pyridine dicarboxylic acid $(0.66 \mathrm{mmol})$ in dehydrated methanol to obtain brown colored solution after 90 min stirring. To this 4 -amino, 1,2,4-triazole $(0.5 \mathrm{mmol})$ was added under slow addition and constant stirring, this produced dark green color. The resulting solution was further stirred for $180 \mathrm{~min}$ at room temperature, allowed to stand in dark, filtered, and left for evaporation in the air at ambient temperature. After one week, green crystals of the complex suitable for X-ray analysis were extracted (yield, 60\%). The recrystallized sample was subjected to elemental analysis: Anal. Calc. for $\mathrm{C}_{16} \mathrm{H}_{11} \mathrm{Fe}_{2} \mathrm{~N}_{6} \mathrm{O}_{8}: \mathrm{C}, 40.79 ; \mathrm{H}, 2.35 ; \mathrm{N}, 17.84$. Found: C, 40.45; H, 2.33; N, 17.82\%. FT-IR (KBr disk, $\left.\mathrm{cm}^{-1}\right): 3359$ (br); 3234( $\left.v \mathrm{NH}\right) ; 3083 ; 2430 ; 1650(\mathrm{~s})\left(v_{\text {asym }} \mathrm{COO}^{-}\right)$,

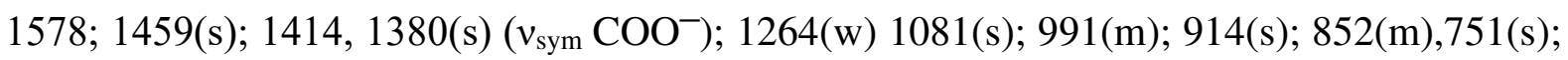
699(s), 671, 619(s); 584(m); 511(s); 414(m). UV-Vis is in $\mathrm{H}_{2} \mathrm{O}\left(\lambda_{\max }, \mathrm{nm}\left(\varepsilon, \mathrm{dm}^{3} / \mathrm{mol} \mathrm{cm}\right)\right)$ : 255 (31434.22), 270 (30800.17); 670 (0.84656); 477 (2.11640).

\subsection{Synthesis of Tin Oxide Nanospheres}

All the chemicals used in this experiment were AR grade. Tin oxide nanoparticles were synthesized with a modified route using dimethyl oxalate as the precipitator [29]. Stannous chloride $\left(\mathrm{SnCl}_{2} .2 \mathrm{H}_{2} \mathrm{O}, 0.1 \mathrm{M}\right)$ was dissolved in 1-propanol under magnetic stirring for $15 \mathrm{~min}$, leading to a transparent solution. To this, dimethyl oxalate $(0.1 \mathrm{M})$ dissolved in distilled water was added in drops and regulated over a period of $10 \mathrm{~min}$. The obtained precipitate was transferred into $150 \mathrm{ml}$ Teflon-lined autoclave and kept at $200^{\circ} \mathrm{C}$ for $12 \mathrm{~h}$ then cooled to room temperature, centrifuged, washed several times with $10 \%$ ethanol in water. Afterwards, the precipitate was dried in an oven at $110^{\circ} \mathrm{C}$ for $10 \mathrm{~h}$ and annealed at $500^{\circ} \mathrm{C}$ for $3 \mathrm{~h}$.

\subsection{Synthesis of Titanium Dioxide Nanospheres}

The starting solution was prepared by adding titanium isopropoxide ( $0.4 \mathrm{M}$, Aldrich) in $30 \mathrm{ml}$ of 1-propanol and to this Triton X-100 surfactant (0.04 M) was added followed by slow addition of $0.5 \mathrm{M}$ of urea with constant stirring. The mass was then allowed to stand $1 \mathrm{~h}$ at room temperature to complete the precipitation. The precipitate formed was transferred into $150 \mathrm{ml}$ autoclave and maintained at $200^{\circ} \mathrm{C}$ for $12 \mathrm{~h}$, cooled, filtered, washed with $10 \%$ ethanol in water thrice, dried annealed at $500^{\circ} \mathrm{C}$ for $3 \mathrm{~h}$. 


\subsection{Synthesis of $\mathrm{SnO}_{2} / \mathrm{TiO}_{2}$ Nanocomposite}

Nanocomposite formation is a complex process that consists of dissolution, precipitation, reorganization, and hydrothermal process [30]. Tin oxide nanopowders and titanium isopropoxide were used as source materials for the hybrid material. First, $\mathrm{SnO}_{2}$ nanospheres (300 mg) were dispersed in $30 \mathrm{~mL}$ of 1-propanol by sonication for $1 \mathrm{~h}$ to obtain clear ash dispersion. Second, the simultaneous realization of building up the desired architecture and incorporation of a second functional component in this step makes this method very appealing. Titanium isopropoxide $(0.4 \mathrm{M}$, Aldrich) in $30 \mathrm{ml}$ of 1-propanol was added instantaneously followed by Triton X-100 surfactant $(0.04 \mathrm{M})$ to the dispersed medium. Urea solution $(0.5 \mathrm{M})$ was slowly added to the medium, stirred well, the mass was allowed to stand for $1 \mathrm{~h}$ to obtain the completion of precipitation at room temperature. Third, is the thermal treatment given to the precipitate in $150 \mathrm{ml}$ capacity autoclave raised to a temperature of $200^{\circ} \mathrm{C}$ for $12 \mathrm{~h}$ and cooled. The resultant solid was washed thoroughly with $10 \%$ ethanol and deionized water to remove the impurities, filtered, dried and annealed at $500^{\circ} \mathrm{C}$ for $3 \mathrm{~h}$.

\subsection{Materials and instrumentation}

The structural and phase identification of nanomaterials were carried out employing X-ray diffractometry (PXRD patterns: the range of $2 \theta=10-80^{\circ}$, step scanning using $2 \theta$ increments of $0.02^{\circ}$ and a fixed counting time of $5 \mathrm{secs} / \mathrm{step}$ ) with $\mathrm{Cu}-\mathrm{K} \alpha$ radiation (wavelength of the $\mathrm{X}$ ray source, $\lambda=1.541 \AA$ ). Raman spectra of phases expected in materials under study were collected on the invia, RENISHAW micro-Raman spectrophotometer at room temperature. UV-Vis absorption measurements were carried out on a double beam spectrophotometer (Shimadzu model 2450, Japan) consists of integrating sphere attachment (ISR-2200). Steadystate fluorescence emission was made on the Spex FluoroLog-3 spectrofluorometer (JobinYvon Inc.) using $450 \mathrm{~W}$ Xenon lamp and equipped with a Hamamatsu R928 photomultiplier tube. The instrument works on the principle of time-correlated single-photon counting (TCSPC) technique. Time-resolved fluorescence decay measurements were carried out using Nano-LED $\left(\lambda_{e x}=295 \mathrm{~nm}\right)$ source for excitation (repetition rate $10 \mathrm{kHz}$ ). The photons were collected from the front face of the sample with TBX-4-X single-photon-counting detector. Lifetimes were determined by fitting the data to exponential decay models using software packages.

Cyclic voltammetry data were obtained using Autolab interface electrochemical analyzer consisting of three-electrode configuration; Pt working electrode ( $0.3 \mathrm{~mm}$ diameter), auxiliary electrode (Pt), and $\mathrm{Ag} / \mathrm{AgCl}-\mathrm{KCl}$ (sat.) reference electrode with Nova software, version: 2.9.3743-23, S. No. AUT84470. The Pt working electrode surface was polished with $0.05 \mu \mathrm{m}$ gamma-alumina powder ensuring a clean and uniform electrode surface rinsed thoroughly with 
distilled water and acetone. The FT-IR spectra of the compounds were recorded on a Thermo Nicollet-6700 FT-IR instrument in the range $4000-400 \mathrm{~cm}^{-1}$ (KBr pellet technique).

Single crystal of the complex was mounted on an Oxford Diffraction Xcalibur diffractometer with an Eos (Nova) detector consists of $\omega$ and $\varphi$ scan modes to obtain single crystal analysis. All diffraction measurements were performed at 293(2) K using graphite monochromated MoK $\alpha$ radiation $(\lambda=0.71073 \AA)$. The structure was solved by direct methods and refinement by full-matrix least-squares on F2 using 32-bit Olex 2-1.1 version program. The other computer programs include data collection: CrysAlis PRO (Oxford Diffraction, 2009); cell refinement: CrysAlis PRO, data reduction: CrysAlis PRO, absorption correction: multi-scan (CrysAlis PRO), these programs were used to solve the structure. The structure refinement was undertaken using; 32-bit Olex 2-1.1 version (Oleg Dolomanor and Horst puschmann, Durham University, UK), molecular graphics: ORTEP-3 for windows-version 2.02 (University of Glasgow, 2008), Mercury 2.3 version copyright work belonging to CCDC software package, 32-bit Olex 2-1.1 version software was used to generate material for publications.

The morphology and microstructure of the synthesized sample were examined by scanning electron microscopy. Resolution: 3nm @ 30kV HV mode; 10nm @ 3 kV HV mode Detectors: Secondary Electron; Semiconductor BSE (Quad type) Magnification: 5 x to 300,000x; Vacuum System: TMP \& Rotary to $1.5 \times 10^{-3} \mathrm{~Pa}$ Specimen Stage: Motorised 5-axis, Eucentric Specimen height: $80 \mathrm{~mm}$ at $10 \mathrm{~mm}$ W.D. and TEM investigations, the samples were prepared by placing a drop of oxide powder and ultrasonically dispersing in aqueous medium. Microstructure analysis was undertaken on a high-resolution transmission electron microscope (HRTEM) JEM 3010 JEOL (Tokyo, Japan) equipped with a field emission gun operating at $200 \mathrm{kV}$, a high brightness $\mathrm{LaB}_{6}$ filament electron source, and image processing by digital micrograph software. Microscopic feature (AFM) of prepared $\mathrm{SnO}_{2} / \mathrm{TiO}_{2}$ nanocomposites, bare $\mathrm{SnO}_{2}$, and $\mathrm{TiO}_{2}$ nanoparticles at $300 \mathrm{~K}$ were collected on a Universal Scanning Probe Microscope (Innova SPM) in tapping mode imaging using glass plate with the size range of $1 \mathrm{~mm} \times 1 \mathrm{~mm}$. The nanoparticles are dispersed in an aqueous medium, drop-casted on the glass plate, and keep it spin coating machine. After spin-coating, the sample has dried at $60-70^{\circ} \mathrm{C}$, then analyzed for atomic force microscopy. The magnetic properties of the sample were observed on a vibrating sample magnetometer, quantum design magnetic property measurement system (Lake Shore,7404) equipped with a reciprocating sample option (vibration frequency: $82.5 \mathrm{~Hz}$; magnet: 400" (200" at Pole face); max field: 15 kGauss; moment range: $1 \mu \mathrm{emu}$ to $56 \mathrm{emu}$; and 80-1400 K temperature). 


\subsection{Surface adsorption experiments}

Surface adsorption property of iron(III) dipicolinato complex, $\left(\mathrm{NH}_{3}-\operatorname{trz}\right)\left[\mathrm{Fe}(\mathrm{dipic})_{2}\right]$, on $\mathrm{SnO}_{2} / \mathrm{TiO}_{2}$ nanocomposite, nano $\mathrm{SnO}_{2}$ and nano $\mathrm{TiO}_{2}$ was examined by dispersing $300 \mathrm{mg}$ of each adsorbent in $100 \mathrm{ml}$ of water. Subsequently, the sorption process was initiated by adding iron(III) complex $\left(9.4478 \times 10^{-6} \mathrm{M}\right)$ in neat water and in binary solvents $\left(\mathrm{H}_{2} \mathrm{O}: \mathrm{Pr}^{\mathrm{i}} \mathrm{OH}=70: 30\right.$; $\left.\mathrm{H}_{2} \mathrm{O}: \mathrm{CH}_{3} \mathrm{CN}=70: 30 ; \mathrm{H}_{2} \mathrm{O}: D M S O=70: 30 ; \mathrm{H}_{2} \mathrm{O}: \mathrm{Bu}^{\mathrm{t} O H}=70: 30(\mathrm{v} / \mathrm{v})\right)$. All equilibrium sorption experiments were conducted at $25{ }^{\circ} \mathrm{C}$ in dark at neutral $\mathrm{pH}$, ionic strength was maintained by adding $1 \mathrm{M}$ of $\mathrm{NaClO}_{4} \cdot \mathrm{H}_{2} \mathrm{O}$, purged with nitrogen gas in $125 \mathrm{~mL}$ stoppered bottle. The flask was sealed, sonicated to adsorption-desorption equilibrium, and transferred to a rotatory shaker to perform an adsorption experiment at room temperature. The adsorption process of iron(III) complex on nanosphere particles was examined by following the change of the electronic absorption spectrum. Adsorption experiments were conducted by exposing iron(III) complex on nanoparticles with different time intervals $(0,5,10,15,30,45$, and 60 $\min )$. The particles were separated from the suspension by centrifugation and the concentration of $\left(\mathrm{NH}_{3}\right.$-trz $)\left[\mathrm{Fe}(\text { dipic })_{2}\right]$ complex was estimated from UV-Vis spectral analysis $(\lambda=\sim 480 \mathrm{~nm})$ with a Shimadzu spectrophotometer.

\subsection{Photocatalytic Test}

A homemade three-jacket quartz immersion well reactor was designed with an internal light source (low-pressure mercury-vapor lamp $\lambda=254 \mathrm{~nm}, 6 \mathrm{~W}$, Heber Scientific; model: LX1108). Potassium ferrioxalate, $\mathrm{K}_{3}\left[\mathrm{Fe}\left(\mathrm{C}_{2} \mathrm{O}_{4}\right)_{3}\right] \cdot 3 \mathrm{H}_{2} \mathrm{O}$, actinometry $\left(\lambda=254 \mathrm{~nm}, 8.50 \times 10^{17}\right.$ photons/sec) was employed to calculate the intensity of light source [31] The inner jacket was cooled by water circulation and the outer jacket with a capacity of volume $=100 \mathrm{~mL}$ was devoted to photolyte solution containing a magnetic pellet. Photolyte solution consists of nanoparticles $(300 \mathrm{mg}),\left(\mathrm{NH}_{3}-\mathrm{trz}\right)\left[\mathrm{Fe}(\text { dipic) })_{2}\right]$ complex $\left(9.4478 \times 10^{-6} \mathrm{M}\right)$ and $1 \mathrm{M}$ $\mathrm{NaClO}_{4} \cdot \mathrm{H}_{2} \mathrm{O}$ in neat water and in binary solvents $\left(\mathrm{H}_{2} \mathrm{O}: \operatorname{Pr}{ }^{\mathrm{i}} \mathrm{OH}=70: 30 ; \mathrm{H}_{2} \mathrm{O}: \mathrm{CH}_{3} \mathrm{CN}=70: 30\right.$; $\left.\mathrm{H}_{2} \mathrm{O}: \mathrm{DMSO}=70: 30 ; \mathrm{H}_{2} \mathrm{O}: \mathrm{Bu}^{\mathrm{t}} \mathrm{OH}=70: 30(\mathrm{v} / \mathrm{v})\right)$. The solution was sonicated in dark to obtain dispersion and to allow adsorption-desorption equilibrium between iron(III) complex and nanoparticle surface. The photocatalytic reaction was started by switching on the UV lamp and samples were discontinuously taken at various times during the irradiation $(0,3,6,9,12,18$ min). Sampling analysis was performed using a syringe and the accuracy of the experiment was verified by repeated blank experiments (analytical absorbance, $\lambda=\sim 480 \mathrm{~nm}$ ). Photoreduction efficiency was calculated using the equation $X=\left[C_{t}-C_{0} / C_{t}\right]$ x 100 (where $X$ is the photo efficiency, $C_{0}$ is the initial concentration of the complex and $C_{t}$ is the concentration of the complex after reduction of Fe(III) ions). The generation of hydroxyl radical formation during heterogeneous catalysis was identified by systematic calibration of the emission of 7 - 
$\mathrm{OH}$ coumarin, which is a highly fluorescent product. A certain quantity of coumarin $\left(1 \times 10^{-3}\right.$ M) was dissolved in $100 \mathrm{ml}$ of water and $300 \mathrm{mg}$ of catalyst dispersed, the mixture was placed under ultra-violet irradiation for $60 \mathrm{~min}$. After irradiation, the mixture was filtered and measured by fluorescence spectra at excitation wavelength of $450 \mathrm{~nm}$.

\section{Results and Discussion}

\subsection{Characterization of ( $\mathrm{NH}_{3}$-trz) $[\mathrm{Fe}($ dipic) 2$]$ Complex}

\subsection{Description of crystal structure}

As presented from X-ray analysis crystal data, the complex $\left(\mathrm{NH}_{3}-\mathrm{trz}\right)\left[\mathrm{Fe}(\text { dipic })_{2}\right]$ crystallizes in orthorhombic space group $P 2{ }_{1}{ }_{1}{ }_{2}{ }_{1}$. The asymmetric unit of complex reported here comprises of an $\left[\mathrm{Fe}(\text { dipic })_{2}\right]^{-}$anion with inorganic counter cation of 4-amino-4H-1,2,4-trizol-4-ium. As depicted in Fig.1, the crystal structure of Fe(III) ion is coordinated with two equivalent of pyridine-2,6-dicarboxylic acids of four carboxylate oxygen atom in equatorial position and two pyridine nitrogen atoms coordinated in axial positions. Fe(III) complex has distorted trans$\mathrm{N}_{2} \mathrm{O}_{4}$ octahedral of two tridentate pyridine-2,6-dicarboxylic acid ligands which are almost in a perpendicular position and $\mathrm{Fe}(\mathrm{III})$ ion is situated on a crystallographic fourfold rotoinversion axis [32, 33]. The crystal structure data, structural refinement, and geometric parameters are presented in Table 1,T1. The bond angles of O1-Fe1-O2 and O3-Fe1-O4 of two trans oxygen and nitrogen atoms (N1-Fe1-N2) of pyridine-2,6-dicarboxylic acid ligands are $150.39^{\circ}$ and $174.27^{\circ}$, respectively. The Fe-N and Fe-O bond distances in the anionic complex are in the range 2.059(2) up to 2.055(1) $\AA$ and 2.002(1) up to 2.060(1) $\AA$, respectively [34]. These bonds are comparable with those reported for $\left(\mathrm{NH}_{3}-\mathrm{trz}\right)\left[\mathrm{Fe}(\text { dipic) })_{2}\right]$ complex, where $\mathrm{Fe}-\mathrm{N}$ bond distances are in the range 2.058(1) up to 2.068(1) $\AA$, and the Fe-O bond distances are in the range from 2.012(1) up to $2.035(1) \AA[35,36]$. In the complex, the intermolecular hydrogen bonds comprising the $\mathrm{N}-\mathrm{H}$ groups of the inorganic counter ion and the pyridine $\mathrm{C}-\mathrm{H}$ groups as donors and the non-coordinating oxygen atoms of the carboxylate groups as acceptors [length $\mathrm{d}(\mathrm{O} \ldots \mathrm{H})$ and angle $<(\mathrm{N}-\mathrm{H} . . . \mathrm{O})$ vary from $2.736(3)$ to $3.020(3) \AA$ and $141-169^{\circ}$, respectively] form into the 3D supramolecular networks. The N-H...O hydrogen bonds are obtained between uncoordinated 4-amino-4H-1,2,4-trizole molecules (N3) and between atrazine nitrogen atoms (N4) and carboxylate oxygen atoms $(\mathrm{O} 7, \mathrm{O} 8)$ of [Fe(dipic) $]^{-}$anions [37]. The existence of weaker $\pi \ldots . . \pi$ stacking relationships between the pyridine rings also leads to the crystal structure stability.

\subsection{HR-MS analysis}

High-resolution mass spectrometry (HRMS) analysis was performed to confirm the formation of $\left(\mathrm{NH}_{3}-\mathrm{trz}\right)\left[\mathrm{Fe}(\mathrm{dipic})_{2}\right]$ complex. As presented in Fig. 2, the observed isotopic ionic peak obtained by dilution of acetonitrile in water. A set of ion peak signals obtained at $\mathrm{m} / \mathrm{z}, 472.0056$ 
corresponds to the $[\mathrm{M}+\mathrm{H}]^{+}$, which is ascribed to the monoanionic complex of $\left(\mathrm{NH}_{3}-\right.$ trz) $\left[\mathrm{Fe}(\text { dipic) })_{2}\right.$; Calc: 470.9988 and this result gave remarkable evidence of the formation of the complex.

\subsection{UV-Vis Spectrum}

The electronic transitions of the anionic complex $\left(\mathrm{NH}_{3}-\mathrm{trz}\right)\left[\mathrm{Fe}(\text { dipic })_{2}\right]$ were characterized by UV-Visible spectroscopy in neat water in the region of $200-800 \mathrm{~nm}$ as depicted in Fig. S1. The complex exhibits four absorption bands at $670,477,270,255 \mathrm{~nm}$. The absorption bands can be assigned to the intra-ligand transitions including $n \rightarrow \pi$ at $\lambda=255$ and $270 \mathrm{~nm}$ due to the dicarboxylate ligand. The UV-Visible spectrum of complex shows ligand to metal charge transfer transition at $\lambda=477 \mathrm{~nm}$ and can be assigned to ${ }^{6} A_{1} \rightarrow{ }^{4} E,{ }^{4} A_{1}\left({ }^{4} G\right)$. The weak and broad absorption bands are observed at $670 \mathrm{~nm}$ can be ascribed to the ${ }^{4} T_{1}\left({ }^{4} G\right) \rightarrow{ }^{6} A_{l}$ transition $\left(d^{5}\right.$ iron(III)) with the high spin state, the transition is both spin forbidden and orbital forbidden [38]. The spectral redshift of the visible absorption bands relative to $\left[\mathrm{Fe}(\mathrm{dipic})_{2}\right]^{-}$has been studied and assisted by the cathodic shift of the $\mathrm{Fe}(\mathrm{III}) / \mathrm{Fe}(\mathrm{II})$ redox potential of $\left(\mathrm{NH}_{3}-\right.$ $\operatorname{trz})\left[\mathrm{Fe}(\text { dipic })_{2}\right.$ complex.

\subsection{Photophysical analysis}

The photophysical and photochemical properties of transition metal coordination complex have been studied to understand the excited states of complex rapidly developed through photochemistry. Photoluminescence (PL) behaviour of $\left(\mathrm{NH}_{3}-\mathrm{trz}\right)\left[\mathrm{Fe}(\text { dipic })_{2}\right]$ complex has been studied in water at the excitation wavelength of $270 \mathrm{~nm}$ as shown in Fig. S2 to understand the characteristics of the various excited states. The emission bands appear at $\lambda=296,331,378$, 390, 412, 437, 486 and $511 \mathrm{~nm}$ with high and weak energy peaks. The absorption bands appeared at the range between 296-390 nm with a high-intensity energy shoulder of ligands [39]. Fe(III) ion is coordinated with ligands, the emission bands at $378 \mathrm{~nm}$ with slight redshift and weak intensity shoulder enhancement were observed for the emission band of $\left(\mathrm{NH}_{3}-\right.$ trz) $\left[\mathrm{Fe}(\text { dipic })_{2}\right]$ complex [40]. The bands appeared in a blue region between 412 to $486 \mathrm{~nm}$ due to intra-ligand $\pi-\pi *$ transition.

\subsection{Raman Spectrum}

Raman spectral features of $\left.\left(\mathrm{NH}_{3} \text {-trz)[Fe(dipic) }\right)_{2}\right]$ complex were measured $50-2000 \mathrm{~cm}^{-1}$ using an excitation laser power of $784 \mathrm{~nm}$ and are depicted in Fig. S3. Raman spectral bands of $\left(\mathrm{NH}_{3}-\right.$ trz) $[\mathrm{Fe}($ dipic) 2$]$ were observed at 198, 397, 648, 682, 766, 891, 1002, 1094, 1152, 1208, 1383, 1274, 1349, 1453, 1580, 1676, $1728 \mathrm{~cm}^{-1}$. The bands observed at 198 and $397 \mathrm{~cm}^{-1}$ can be ascertained to the symmetric and asymmetric stretching vibrations of $\mathrm{Fe}-\mathrm{O}$ bond in $\left(\mathrm{NH}_{3}-\right.$ trz) $\left[\mathrm{Fe}(\right.$ dipic) 2$]$ complex, respectively. The band appeared at $1349 \mathrm{~cm}^{-1}$ can be ascribed to the disappearance of vibrations of the hydroxyl group $v(\mathrm{OH}), \beta(\mathrm{OH})$ and $\chi(\mathrm{OH})$ as well. The most 
intensive region is observed in $1580,891,1453 \mathrm{~cm}^{-1}$ corresponds to the stretching vibrations of aromatic rings $\left(v_{\mathrm{C}-\mathrm{H}}, v_{\mathrm{C}=\mathrm{N}}, v_{\mathrm{C}-\mathrm{C}}\right)$ and bending $\beta(\mathrm{C}-\mathrm{O})$ vibrations, respectively. The band appeared at $1676-1580 \mathrm{~cm}^{-1}$ can be assigned to the $v_{\mathrm{sym}} \mathrm{COO}^{-}$and $v_{\mathrm{asym}} \mathrm{COO}^{-}$vibrations respectively [41]. The metal ion is substituted on the two carboxylic acid results in the disappearance of the characteristic symmetric and asymmetric vibrations of carboxyl groups. The band appears at 648 and $682 \mathrm{~cm}^{-1}$ can be attributed to vibrations of $\mathrm{Fe}-\mathrm{N}$ and O-Fe-N groups respectively [42].

\subsection{Electrochemical measurements}

The redox behavior of $\left(\mathrm{NH}_{3}\right.$-trz) $\left[\mathrm{Fe}(\text { dipic })_{2}\right]$ complex was investigated by cyclic voltammetry in acetonitrile at room temperature. The experiments were carried out using a three-electrode system (working electrode as platinum foil, counter electrode as platinum rod, and $\mathrm{Ag} / \mathrm{AgCl}$ in $\mathrm{KCl}$ (sat.) as reference electrode) and tetrabutylammonium perchlorate as the supporting electrolyte. A cyclic voltammogram of $\left(\mathrm{NH}_{3}-\mathrm{trz}\right)$ [Fe(dipic) $)_{2}$ complex is displayed in Fig. 3 and exhibits one quasi-reversible reduction region and one irreversible region and the potential values are presented in the Table T2 at various scan rates: 50-350 mV/s. First quasi-reversible reduction region corresponds to the ligands; can be associated with an anodic region at -1.1920 $\mathrm{V}$ coupled with a cathodic region at $-1.2096 \mathrm{~V}$ [43]. The first reduction potential observed is more negative represents ligand-based reduction behaviour showing superior electron donor effect influences the electrochemical properties of $\left(\mathrm{NH}_{3}\right.$-trz $)\left[\mathrm{Fe}(\text { dipic })_{2}\right]$ complex. Second irreversible cathodic region appears at $0.6896 \mathrm{~V}$. The second reduction potential peak can be ascribed to $\mathrm{Fe}(\mathrm{III}) / \mathrm{Fe}(\mathrm{II})$ generation in the anionic complex ion [44, 45].

\subsection{FT-IR Analysis}

Fourier transform infra-red spectroscopy reveals vibrations of functional groups such as the N$\mathrm{H}$ group coordinated to 4-amino-4H-1,2,4-trizol-4-ium cation, nitrogen atom and aromatic $\mathrm{CHs}$ of pyridine dicarboxylate groups and binding interaction of metal to the ligand in the complex. As depicted in Fig. S4, the strong bands at 1650 and $1380 \mathrm{~cm}^{-1}$ can be attributed to asymmetric $\left(v_{\text {asym }}\left(\mathrm{COO}^{-}\right)\right)$and symmetric $\left(v_{\text {sym }}\left(\mathrm{COO}^{-}\right)\right)$stretching vibrations of the carboxyl acid groups, respectively. The separation between asymmetric and symmetric vibrations of $\mathrm{COO}^{-}$groups are in the range $306-372 \mathrm{~cm}^{-1}$, which indicates that the carboxylic group is coordinated to the central metal Fe(III) ion. The band at $735-752 \mathrm{~cm}^{-1}$ and $619-699 \mathrm{~cm}^{-1}$ can be ascribed to the vibrations of $v_{\mathrm{O}-\mathrm{C}-\mathrm{O}}$ in dipicolinate ring and wagging vibrations of pyridine ring $[46,47]$. The strong and broad absorption bands at $1595-1602 \mathrm{~cm}^{-1}$ can be assigned to $v_{\mathrm{C}=\mathrm{N}}$. The broad absorption bands at $3234-3479 \mathrm{~cm}^{-1}$ can be attributed to the $\mathrm{O}-\mathrm{H}$ groups in the crystal lattice 
and $v_{\mathrm{N}-\mathrm{H}}$ of the inorganic cation of counter-ion of 4-amino-1,2,4-triazole moiety as disclosed by the X-ray crystal structure $[48,49]$.

\subsection{Magnetic property}

The magnetic property of $\mathrm{Fe}^{3+}$ ion in $\left(\mathrm{NH}_{3}-\mathrm{trz}\right)\left[\mathrm{Fe}(\text { dipic })_{2}\right]$ complex was measured at room temperature by vibrating sample magnetometer as presented in Fig. 4a. The saturation magnetization was measured in the range between \pm 3000 Oe. A low saturation magnetic moment $\mathrm{M}_{\mathrm{s}}=0.1285$ to $-0.1294 \times 10^{-3} \mathrm{emu} / \mathrm{g}$ and coercive field $\mathrm{H}_{\mathrm{c}}=59.08$ to $65.58 \mathrm{emu} / \mathrm{g}$ were observed. The linear curve of iron (III) complex shows paramagnetic nature to the applied magnetic field versus magnetization, which identifies that the mononuclear arrangement of iron (III) complex with 2,6-pyridine dicarboxylic acids and 4-amino-1,2,4-triazole complex. In complex, $\left[\mathrm{Fe}(\text { dipic })_{2}\right]^{-}$anion binding properties of the more electron-donating group and average bond lengths of $\mathrm{Fe}-\mathrm{N}$ (2.0551 (3) $\AA$ ) are closely related to high-spin molecules at room temperature [50].

\section{Characterization of nanocomposite photocatalyst}

\subsection{PXRD analysis}

The crystal structures and phase purity of hydrothermally prepared bare $\mathrm{SnO}_{2}, \mathrm{TiO}_{2}$ nanospheres, and $\mathrm{SnO}_{2} / \mathrm{TiO}_{2}$ nanocomposite were characterized by powder X-ray (XRD) spectroscopy. Fig. 5 exhibits all the diffractions peaks well indexed to the pure tetragonal phase (space group $P 4_{2} / \mathrm{mnm}$ ) of $\mathrm{SnO}_{2}$ (JCPDS card No. 041-1445) [51]. The XRD pattern of $\mathrm{SnO}_{2} / \mathrm{TiO}_{2}$ nanocomposite can be easily distinguished with two separate phases from the mixture, the smaller particle size of the anatase phase of $\mathrm{TiO}_{2}$ combined with the slightly larger particle size of the tetragonal phase of $\mathrm{SnO}_{2}[52,53]$. After annealing at $\sim 500^{\circ} \mathrm{C}$ for $3 \mathrm{~h}$, the absence of impurities or secondary phase was inducted as supported in the XRD analysis. All diffraction peaks of bare $\mathrm{TiO}_{2}$ nanospheres are well indexed to anatase phase and matched with the standard pattern (JCPDS card No. 021-1272) [54]. The mean crystallite particle size of the samples of $\mathrm{SnO}_{2} / \mathrm{TiO}_{2}$ nanocomposite, nano $\mathrm{SnO}_{2}$, and $\mathrm{TiO}_{2}$ were calculated by using the Scherrer equation, $D=0.9 \lambda / \beta(\cos \theta)$, where, $\lambda$ is the wavelength of the $\mathrm{X}$-ray $(1.54 \AA), \beta$ is the full-width at half maximum (FWHM) in radians, and $\theta$ is the Bragg angle in the diffraction pattern. From this equation, the mean crystalline particle size was estimated to be $35.36 \mathrm{~nm}$, $32.09 \mathrm{~nm}$, and $66.42 \mathrm{~nm}$ and different parameters are presented in Table 2. Consequently, it could be deduced that the $\mathrm{SnO}_{2}$ tetragonal phase and $\mathrm{TiO}_{2}$ anatase phase coexisted in these nanocomposites, in good agreement with the SEM and TEM results.

\subsection{Raman Analysis}

Raman spectroscopy is one of the versatile characterization tool for hydrothermally prepared $\mathrm{SnO}_{2} / \mathrm{TiO}_{2}$ nanocomposite, bare $\mathrm{SnO}_{2}$ and $\mathrm{TiO}_{2}$ nanospheres at the excitation wavelength of 
$784 \mathrm{~nm}$ as shown in Fig. 6 and presented in Table 2. As can be seen, the rutile phase of $\mathrm{SnO}_{2}$ has a $D_{4 h}$ symmetry with two formula units per primitive cell and lattice constants $\mathrm{a}=\mathrm{b}=$ $4.7373 \AA$ and $\mathrm{c}=3.1864 \AA$ [55]. The Raman scattering spectra of $\mathrm{SnO}_{2}$ has three vibrational active modes $A_{l g}, E_{g}$, and $B_{2 g}$ were identified and corresponding to 445,624 , and $775 \mathrm{~cm}^{-1}$ modes respectively. The anatase phase of $\mathrm{TiO}_{2}$ has a tetragonal symmetry with point group $4 / m m m$, four active modes are observed $141 \mathrm{~cm}^{-1}\left(E_{g}\right), 394 \mathrm{~cm}^{-1}\left(B_{1 g}\right), 514 \mathrm{~cm}^{-1}\left(A_{1 g}\right), 637 \mathrm{~cm}^{-}$ ${ }^{1}\left(E_{g}\right)$ [56]. The anatase modification has six Raman active modes $\left(A 1_{g}+2 B 1_{g}+3 E_{g}\right)$. In single crystals, these modes are located at $144\left(E_{g}\right), 197\left(E_{g}\right), 399\left(B 1_{g}\right), 513\left(A l_{g}\right), 519\left(B 1_{g}\right)$, and $639 \mathrm{~cm}^{-1}\left(E_{g}\right)$. All these lines are present in the observed spectra. The $E_{g}$ band can be assigned to the symmetric stretching vibration of O-Ti-O, the $B_{1 g}$ peak is corresponding to the symmetric bending vibration of $\mathrm{O}-\mathrm{Ti}-\mathrm{O}$, and the $A_{l g}$ can be ascribed to the anti-symmetric bending vibration of $\mathrm{O}-\mathrm{Ti}-\mathrm{O}$ in $\mathrm{TiO}_{2}$ [57]. Raman spectra confirmed that no additional peaks existed in the composites and bare components belong to impurity.

\subsection{Microstructure analysis}

The surface morphology of $\mathrm{SnO}_{2}$ and $\mathrm{TiO}_{2}$ nanospheres and $\mathrm{SnO}_{2} / \mathrm{TiO}_{2}$ nanocomposite annealed at $500^{\circ} \mathrm{C}$ were investigated by the SEM and TEM images. The low magnified SEM images of all the samples in Fig. 7a-d depicts a large quantity of slightly aggregated, welldefined spherical shape in morphology and good uniform in size. The TEM images further confirm that existence of spherical morphology in composites with $\mathrm{SnO}_{2}$ nanoparticles well dispersed on the surface of $\mathrm{TiO}_{2}$ nanoparticles uniformly by the hydrothermal method are shown in Fig. 8, S5 and S6. The particle size histogram of the samples $\mathrm{SnO}_{2}, \mathrm{SnO}_{2} / \mathrm{TiO}_{2}, \mathrm{TiO}_{2}$ was found to be $30-60 \mathrm{~nm}, 20-50 \mathrm{~nm}$, and $15-45 \mathrm{~nm}$ respectively. The lattice $\mathrm{d}$ spacing observed at $0.33 \mathrm{~nm}$ and $0.35 \mathrm{~nm}$ can be assigned to the $\mathrm{SnO}_{2}$ and $\mathrm{TiO}_{2}$ nanoparticles. In the SAED pattern, the $\mathrm{SnO}_{2} / \mathrm{TiO}_{2}$ nanocomposites four-fold symmetric diffraction spots correspond to the presence of $\mathrm{SnO}_{2}$ and $\mathrm{TiO}_{2}$ nanoparticles. While a series of concentric circles correspond to the electron diffraction of (101), (110), (210) planes of the crystal [58]. AFM imaging demonstrated useful information as a feature dispersion in aqueous medium regarding the various agglomeration tendencies. Fig. 9a-f shows two and three-dimensional atomic force microscopic images of $\mathrm{SnO}_{2}, \mathrm{SnO}_{2} / \mathrm{TiO}_{2}$ and $\mathrm{TiO}_{2}$ nanoparticles on a glass substrate. The images were recorded at the scan rate of $10.17 \mathrm{~Hz}$ of $1 \mu m \mathrm{x} 1 \mu \mathrm{m}$ planar in contact mode. $\mathrm{SnO}_{2}$ nanoparticle sample is not uniformly distributed with spherical grains of varying size of 500 $\mathrm{nm}$ magnifications. $\mathrm{TiO}_{2}$ nanoparticles shown the uniform size with spherical shape was observed. The average particle size ranges between $15-59 \mathrm{~nm}$, resulting in very good agreement with SEM and TEM Images. $\mathrm{SnO}_{2} / \mathrm{TiO}_{2}$ nanocomposites are irregular dispersion of two 
distinct interaction of bare nanoparticles with spherical shape appeared at $400 \mathrm{~nm}$ magnifications [59].

\subsection{Optical Properties}

Fig. 10a displays the UV-Vis absorption spectra of $\mathrm{TiO}_{2}$ and $\mathrm{SnO}_{2}$ nanospheres and the nanocomposite, indicating the light-harvesting capacity in the region 205-335 $\mathrm{nm}$. The absorption curves illustrate adsorption edge at $\sim 360 \mathrm{~nm}, \sim 400 \mathrm{~nm}$ and $\sim 395 \mathrm{~nm}$ can be observed to nano $\mathrm{SnO}_{2}, \mathrm{SnO}_{2} / \mathrm{TiO}_{2}$ nanocomposite and nano $\mathrm{TiO}_{2}$ respectively are presented in Table 2. The optical band gap energy of the samples was estimated by Tauc approach according to the following equation $(\alpha h v)^{n} \alpha\left(h v-E_{g}\right)$, where $\alpha, h v$, and $E_{g}$ are the absorption coefficient, photon energy, and bang gap, respectively. In the relationship, $n$ is related to the characteristics of the transition of a semiconductor (indirect transition: $n=1 / 2$; direct transition: $n=2)[60,61]$. The direct transition of semiconductor samples is the plot of $(\alpha h v)^{2}$ against $h v$ as shown in Fig. 10b, the bandgap values are found to be 3.69, 3.30, $3.28 \mathrm{eV}$ for $\mathrm{SnO}_{2}$, $\mathrm{SnO}_{2} / \mathrm{TiO}_{2}$ nanocomposite, and $\mathrm{TiO}_{2}$ respectively. $\mathrm{SnO}_{2} / \mathrm{TiO}_{2}$ nanocomposite could absorb photon on the selective region of UV and visible range indicating promising UV-Visible light photocatalyst.

\subsection{Photoluminescence Spectra and Life time studies}

Photoluminescence (PL) spectra of nanostructured materials convey the charge separation and photogenerated electron/hole recombination characteristics of the photocatalyst. The steadystate photoluminescence (PL) spectra of nano $\mathrm{SnO}_{2}, \mathrm{SnO}_{2} / \mathrm{TiO}_{2}$ nanocomposite, and nano $\mathrm{TiO}_{2}$ exhibit predominant emission peak at $\lambda \sim 400 \mathrm{~nm}$, two sub-peaks at $\lambda \sim 467$ and $521 \mathrm{~nm}$, and additionally very weak peaks as depicted in Fig. 11a. It is imperative to understand that the emission is caused by the recombination, and free excitons as well as bound excitons (selftrapped excitons). It becomes also clear that the sub-peaks observed are induced surface defect states if compared with energetic positions. It is well known that lowering peak intensity refers to delay in electron/hole recombination, higher charge separation efficiency, and resulted in better photocatalytic activity [62]. The intensity of emission decreased in the order: nano $\mathrm{SnO}_{2}$ $(421 \mathrm{~nm})>$ nano $\mathrm{TiO}_{2}(398 \mathrm{~nm})>>\mathrm{SnO}_{2} / \mathrm{TiO}_{2}$ nanocomposite $(397 \mathrm{~nm})$. Table 2 illustrates the high-intensity emission band at $\sim 400 \mathrm{~nm}$ (weak ultraviolet emission) is assigned to selftrapped excitons and $\sim 467 \mathrm{~nm}$ free excitons [63]. The $\sim 520 \mathrm{~nm}$ (green emission) is due to band-band transition along with a set of weak intensity emission bands mentioning the formation of a significant number of trapped states, which are responsible for various PL signals in the visible region [64]. Currently, an important experimental technique, timeresolved photoluminescence (TRPL) is frequently carried out to probe the recombination dynamics of the photogenerated charge carriers. Kinetic analysis data on the intensity decay 
profile of the emission caused by the recombination of electron/hole and excitons and the lifetime distributions are illustrated. The curve implies the multi-exponential decay, in coincidence with three decay durations $\tau_{1}, \tau_{2}$, and $\tau_{3}$ lifetime scales. These lifetime components can be fitted in the relation: $\mathrm{A}+\mathrm{B}_{1} \exp \left\{-\tau / \tau_{1}\right\} \mathrm{B}_{2} \exp \left\{-\tau / \tau_{2}\right\} \mathrm{B}_{3} \exp \left\{-\tau / \tau_{3}\right\}$ to produce timeresolved dynamics of carriers, a more direct and important technique behind the high activity of prepared photocatalyst. The room temperature time-decay curve of the nano $\mathrm{SnO}_{2}$, nano $\mathrm{TiO}_{2}$ and $\mathrm{SnO}_{2} / \mathrm{TiO}_{2}$ nanocomposite (excitation wavelength at $292 \mathrm{~nm}$, Fig. 11b-d fits well to a triexponential function $\left(\mathrm{I}=\Sigma_{\mathrm{n}} A_{\mathrm{n}} \exp \left(-\mathrm{t} / \tau_{\mathrm{n}}\right)\right.$ ), where $A_{n}$ and $\tau_{n}$ represent the amplitude and lifetime of the component, respectively. The fast component, $\tau_{l}$, represents the near band edge relaxation lifetime, and the second one, $\tau_{2}$, indicates photogenerated charge carriers relaxation lifetime of the shallow-trap states. The fast lifetime associated with, $\tau_{3}$, can be matched with deep state relaxation of the photogenerated charge carriers [65]. The average PL lifetime $\left(\tau_{\text {avg }}\right)$ of each samples can be calculated using this equation: $\tau_{\text {avg }}=\left(\mathrm{B}_{1} \tau_{1}^{2}+\mathrm{B}_{2} \tau_{2}^{2}+\mathrm{B}_{3} \tau_{3}^{2}\right) / \mathrm{B}_{1} \tau_{1}+\mathrm{B}_{2} \tau_{2}$ $\left.+\mathrm{B}_{3} \tau_{3}\right)$ and are presented in Table 2 . This is equated with the efficiency of the various nanoscale photocatalysts of $\mathrm{SnO}_{2}(32.59 \mathrm{~ns}) \mathrm{TiO}_{2}(34.70 \mathrm{~ns})$ nanospheres, and $\mathrm{SnO}_{2} / \mathrm{TiO}_{2}$ nanocomposite (37.77 ns) at an excitation wavelength of $292 \mathrm{~nm}$. The lifetime of excitons is increased for the nanocomposites since additional intermediate states introduced to reduce the recombination of charge carriers to act as best photocatalyst [66].

\subsection{FT-IR analysis}

Fourier transform infrared spectroscopy (FTIR) is an important and informative technique, which confirms the existence of the nature of the chemical bonding of metal oxide composites. Fig. S7 shown that the FT-IR spectra for $\mathrm{SnO}_{2} / \mathrm{TiO}_{2}$ composites and bare components in the region of 4000-400 $\mathrm{cm}^{-1}$. The characteristic vibrational peaks at 513 and $631 \mathrm{~cm}^{-1}$ are attributed to the $\mathrm{Sn}-\mathrm{O}$ and $\mathrm{Sn}-\mathrm{O}-\mathrm{Sn}$ stretching vibrations of $\mathrm{SnO}_{2}$ respectively [67]. The vibrational modes between 730 to $470 \mathrm{~cm}^{-1}$ can be assigned to Ti-O-Ti stretching vibrations [68]. The broad region between $460-715 \mathrm{~cm}^{-1}$ obtained shows the co-existence of $\mathrm{Sn}-\mathrm{O}-\mathrm{Ti}$ vibrations in the composites [69].

\subsection{Magnetic property analysis}

The magnetic properties of the as-prepared nanocomposite were also explored for their inherent magnetic characteristics. The $M-H$ curves of $\mathrm{SnO}_{2} / \mathrm{TiO}_{2}$ nanocomposites, bare $\mathrm{SnO}_{2}$ and $\mathrm{TiO}_{2}$ nanospheres are depicted in Fig. 4b-d at room temperature. All the samples show a hysteresis loop with ferromagnetic behaviour. It could be the existence of either oxygen vacancies or cation vacancies present in the samples. The saturation magnetization, coercivity and magnetic remanence values of $\mathrm{SnO}_{2} / \mathrm{TiO}_{2}$ nanocomposites, bare $\mathrm{SnO}_{2}$ and $\mathrm{TiO}_{2}$ nanospheres are presented in Table T3. The saturation magnetization of nanocomposites is 
much more prominent than the bare $\mathrm{TiO}_{2}$ and $\mathrm{SnO}_{2}$ nanospheres because of the spin reorientation emerging from the spin-spin interface between $\mathrm{Sn}-\mathrm{O}$ and Ti-O dipoles [70]. The spins on the interface layer could have two distinct forms of $\mathrm{SnO}_{2}$ and $\mathrm{TiO}_{2}$ interaction to improve the nanocomposites coercivity and magnetic remanence. In nanocomposites with a strong probability of the existence of uncompensated bonds of $\mathrm{Sn}, \mathrm{Ti}$ and $\mathrm{O}$, there may be a significant amount of lattice mismatch at the synergetic effect of individual nanocomponents. This indicates that the synergetic effect influences magnetism to separate catalyst by the external magnetization.

\section{Surface Adsorption experiments}

The removal of $\left(\mathrm{NH}_{3} \text {-trz)[Fe(dipic) }\right)_{2}$ complex was carried out by batch experimentation in neat water and in binary solvents $\left(\mathrm{H}_{2} \mathrm{O}: \mathrm{Pr}^{\mathrm{i}} \mathrm{OH}=70: 30 ; \mathrm{H}_{2} \mathrm{O}: \mathrm{CH}_{3} \mathrm{CN}=70: 30 ; \mathrm{H}_{2} \mathrm{O}:\right.$ DMSO = $\left.70: 30 ; \mathrm{H}_{2} \mathrm{O}: \mathrm{Bu}^{\mathrm{t} O H}=70: 30(\mathrm{v} / \mathrm{v})\right)$ at room temperature. $300 \mathrm{mg}$ of nanoparticle adsorbent and $1 \mathrm{M} \mathrm{NaClO}{ }_{4} \cdot \mathrm{H}_{2} \mathrm{O}$ as a function of ionic strength of the solution have been used to remove $\left(\mathrm{NH}_{3}\right.$-trz $)$ [Fe(dipic) $)_{2}\left(9.4478 \times 10^{-6} \mathrm{M}\right)$ complex at various time intervals. During all experiments, nanoparticles are well dispersed and the concentration of the complex gradually decreased and finally attained the equilibrium at $60 \mathrm{~min}$. After surface adsorption, the ability of iron(III) complex and nanoparticle interactions are agglomerated and disappearance of the colour of the solution. As can be seen in Fig. 12a, b, the results have shown that the removal efficiency and rate constant of nanocomposites are much higher in the specified solvent medium at 60 min time duration. The apparent photoreaction rate $(k)$ of nanocomposite is $0.0466 \mathrm{sec}^{-1}$, which is higher than the $\mathrm{SnO}_{2}\left(0.0104 \mathrm{sec}^{-1}\right)$ and $\mathrm{TiO}_{2}\left(0.0260 \mathrm{sec}^{-1}\right)$ bare components in $\mathrm{H}_{2} \mathrm{O}$ :DMSO (70:30\%) than the other solvents medium as displayed in Fig. S8. Among the various solvent proportions, the impact of dimethyl sulfoxide (DMSO) gave much higher than the other medium, due to more interaction of complex and nanocomposites. In addition, the effects of solvent on the less formation of hydrogen-bond interaction between template molecules to interact with the surface of the nanoparticles [71-73], could also be the reason that led to the different adsorption capacity and selectivity as presented in Table 3, T4.

\section{Photocatalytic Reduction}

It was explored to deduce the apparent kinetic model to estimate the photocatalytic reduction of $\left(\mathrm{NH}_{3}\right.$-trz) [Fe(dipic) 2 complex by $\mathrm{SnO}_{2}, \mathrm{TiO}_{2}$ nanospheres, and $\mathrm{SnO}_{2} / \mathrm{TiO}_{2}$ nanocomposite in water and binary solvent media under ultra-violet irradiation. Fig.13a, b display the degradation efficiency and rate of photoreduction of $\left(\mathrm{NH}_{3}-\mathrm{trz}\right)\left[\mathrm{Fe}(\mathrm{dipic})_{2}\right]$ complex on the $\mathrm{SnO}_{2} / \mathrm{TiO}_{2}$ heterostructures in water and in binary solvents $\left(\mathrm{H}_{2} \mathrm{O}: \mathrm{Pr}{ }^{\mathrm{i}} \mathrm{OH}=70: 30 ; \mathrm{H}_{2} \mathrm{O}: \mathrm{CH}_{3} \mathrm{CN}\right.$ $\left.=70: 30 ; \mathrm{H}_{2} \mathrm{O}: \mathrm{DMSO}=70: 30 ; \mathrm{H}_{2} \mathrm{O}: \mathrm{Bu}^{\mathrm{t}} \mathrm{OH}=70: 30(\mathrm{v} / \mathrm{v})\right)$ medium at $18 \mathrm{~min}$ time intervals. $\mathrm{SnO}_{2} / \mathrm{TiO}_{2}$ heterostructures showed superior photocatalytic activity rather than bare $\mathrm{SnO}_{2}$ and 
$\mathrm{TiO}_{2}$ nanospheres. In a coupled system, efficient separation of photogenerated electron-hole pairs and less recombination played a significant role in the reduction of the coordination complex. It can be observed that the photo efficiency of $\mathrm{SnO}_{2}, \mathrm{TiO}_{2}, \mathrm{SnO}_{2} / \mathrm{TiO}_{2}$ nanocomposite are $49 \%, 88 \%$, and $91 \%$ in $\mathrm{H}_{2} \mathrm{O} / \mathrm{Pr}^{\mathrm{i}} \mathrm{OH}(70 / 30 \%(\mathrm{v} / \mathrm{v}))$ at $18 \mathrm{~min}$ time duration is higher than the other medium are presented in Table T5. The apparent photoreaction rate $(k)$ of nanocomposite is $0.1432 \mathrm{sec}^{-1}$, which is higher than the $\mathrm{SnO}_{2}\left(0.0373 \mathrm{sec}^{-1}\right)$ and $\mathrm{TiO}_{2}(0.1422$ $\sec ^{-1}$ ) bare components in $\mathrm{H}_{2} \mathrm{O}: \mathrm{Pr}^{\mathrm{i}} \mathrm{OH}(70: 30 \%)$ than the other solvents medium as shown in Fig. S9. The order of the photocatalytic reduction as follows $\mathrm{SnO}_{2} / \mathrm{TiO}_{2}>\mathrm{TiO}_{2}>\mathrm{SnO}_{2}$. The peak intensity of $\left(\mathrm{NH}_{3} \text {-trz)[Fe(dipic) }\right)_{2}$ complex increased significantly, confirming the reduction of $\mathrm{Fe}(\mathrm{III})$ ions. The formation of Fe(II) ion has confirmed by Kitson's technique with the presence of phenanthroline as a complexing agent [74]. The photo efficiency of formation of Fe(II) ion presented in Table T6. The photocatalytic degradation kinetics of the samples were systematically analyzed by fitting the data to the Langmuir-Hinshelwood model. The model is expressed in its simple form as a pseudo-first-order kinetic reaction when the initial dye concentration $\left(C_{0}\right)$ is low, and it is expressed as $\ln C_{0} / C_{t}=k t$ where $C_{t}$ and $C_{0}$ are the initial concentration of complex at time $t=t$ and $t=0$ and $k$ is the reaction rate constant. The values of rate constant for the samples were determined in neat water and binary solvent medium are presented in Table 3. The role of organic reactive species involved in photocatalytic reaction quenching experiments by adding various experiments such as isopropanol, tert-butanol, dimethyl sulfoxide for electrons $\left(\mathrm{e}^{-}\right)$, and hydroxyl radicals $\left({ }^{\circ} \mathrm{OH}\right)$, respectively. The photocatalytic experiments were carried out in the absence and presence of scavengers with these two active species $\left(\mathrm{e}^{-}\right.$and $\left.{ }^{\bullet} \mathrm{OH}\right)$ on $\left(\mathrm{NH}_{3}\right.$-trz) $\left[\mathrm{Fe}(\text { dipic })_{2}\right]$ complex in presence of photocatalyst. During the photolysis experiment, $\mathrm{H}_{2} \mathrm{O} / \mathrm{Pr}^{\mathrm{i}} \mathrm{OH}(70: 30(\mathrm{v} / \mathrm{v}))$ medium were able to trap more number of hydroxyl radical, thus enhancing the availability of electrons to reduce coordination complex more effectively. After photocatalytic reduction of complex, the efficiency of catalyst decreased in the presence of scavengers. It is confirmed that, the reactive species involved in the photocatalytic reduction reactions and the importance of hydroxyl radicals and electrons in the environmental remediation.

\subsection{Mechanism of photodegradation}

The photoconversion of Fe(III) centre into Fe(II) due to effective separation of electron-hole separation in $\mathrm{SnO}_{2} / \mathrm{TiO}_{2}$ nanocomposite is illustrated in Fig. 14. The mechanism of electron flow in the heterojunction of the photocatalyst was calculated by using the EQs (1) and (2) with the band positions of the conduction band $\left(E_{C B}\right)$ and valence band $\left(E_{V B}\right)$ of $\mathrm{SnO}_{2}$ and $\mathrm{TiO}_{2}$ semiconductors.

$$
E_{C B}=\chi-E^{e}-1 / 2 E_{g}
$$




$$
E_{V B}=E_{C B}+E_{g}
$$

where $E_{C B}$ and $E_{V B}$ are the $\mathrm{CB}$ and $\mathrm{VB}$ band edge potential, respectively; $\chi$ is the electronegativity of the semiconducting material, which is the geometric mean of the electronegativity of the constituent atoms; $E^{e}$ is the energy of free electrons on the hydrogen scale $(4.5 \mathrm{eV})$, and $E_{g}$ is the bandgap energy of the semiconductor. The $\mathrm{SnO}_{2}$ and $\mathrm{TiO}_{2}$ conduction band (CB) edges are located at $-0.13 \mathrm{eV}$ and $-0.33 \mathrm{eV}$ relative to the standard electrode of hydrogen (NHE) at $\mathrm{pH}$ 7. The observed difference between $\mathrm{SnO}_{2}$ and $\mathrm{TiO}_{2}$ on the conduction band edges makes it much easier for the photogenerated electrons on the $\mathrm{TiO}_{2}$ surface to migrate to the $\mathrm{SnO}_{2}$ conduction band. This increases the rate of charge separation of the photogenerated charge carriers, while because of their higher VB level, the photogenerated holes accumulate on $\mathrm{TiO}_{2}$. The intensity of the PL signal in the composite has decreased and ascribed to the enhanced charge separation of the photogenerated electron-hole pairs. The electrons in the $\mathrm{TiO}_{2}$ once excited to the $\mathrm{CB}$ get easily transferred to the $\mathrm{CB}$ of $\mathrm{SnO}_{2}$ of the $\mathrm{SnO}_{2} / \mathrm{TiO}_{2}$ nanocomposite. These electrons induce adhered iron(III) dipicolinato, [Fe(dipic) $]^{-}$ , anion and generate photo-reductive products. The holes in the $\mathrm{VB}$ of $\mathrm{SnO}_{2}$ get transferred to $\mathrm{TiO}_{2}$ and reacts with $\mathrm{OH}^{-}$to form hydroxyl radicals. In addition, the lifetime of photogenerated species of composite is higher than bare $\mathrm{SnO}_{2}$ and $\mathrm{TiO}_{2}$ nanospheres. The plausible mechanism is as follows;

$$
\begin{aligned}
& \mathrm{SnO}_{2} / \mathrm{TiO}_{2}+\mathrm{h} v \rightarrow \mathrm{SnO}_{2} / \mathrm{TiO}_{2}\left(\mathrm{e}^{-}+\mathrm{h}^{+}\right) \\
& \mathrm{SnO}_{2} / \mathrm{TiO}_{2}\left(\mathrm{e}^{-}+\mathrm{h}^{+}\right) \rightarrow \mathrm{TiO}_{2}\left(\mathrm{~h}^{+}\right) / \mathrm{SnO}_{2}\left(\mathrm{e}^{-}\right) \\
& \mathrm{TiO}_{2}\left(\mathrm{~h}^{+}\right) / \mathrm{SnO}_{2}\left(\mathrm{e}^{-}\right)+\left(\mathrm{NH}_{3}-\mathrm{trz}\right)\left[\mathrm{Fe}(\text { dipic })_{2}\right] \rightarrow \mathrm{Fe}^{\mathrm{II}} \\
& \mathrm{SnO}_{2}\left(e_{C B}^{-}\right)+\mathrm{O}_{2} \rightarrow \mathrm{O}_{2}^{-} \\
& \mathrm{TiO}_{2}\left(\mathrm{~h}^{+}\right)+\mathrm{OH}^{-} \rightarrow \mathrm{TiO}_{2}+\mathrm{OH}^{\bullet} \\
& \mathrm{TiO}_{2}\left(\mathrm{~h}^{+}\right)+\mathrm{OH}^{\bullet}+\mathrm{O}_{2}^{-}+\rightarrow \mathrm{TiO}_{2}+\mathrm{CO}_{2}+\mathrm{H}_{2} \mathrm{O} \\
& e_{C B}^{-}+\mathrm{O}_{2}^{-}+\mathrm{H}_{2} \mathrm{O} \rightarrow \mathrm{H}_{2} \mathrm{O}^{\bullet}+\mathrm{OH}^{-} \\
& e_{C B}^{-}+\mathrm{H}_{2} \mathrm{O}^{\bullet}+\mathrm{H}^{+} \rightarrow \mathrm{H}_{2} \mathrm{O}_{2} \\
& e_{C B}^{-}+\mathrm{H}_{2} \mathrm{O}_{2} \rightarrow \mathrm{OH}^{\bullet}+\mathrm{OH}^{-}
\end{aligned}
$$

Reactions (3) - (11) imply that the possible pathway of the photocatalytic process.

\subsection{Hydroxyl radical study}

In order to investigate the progress of hydroxyl radicals $\left({ }^{\bullet} \mathrm{OH}\right)$ on the surface of photocatalyst during the photocatalytic reaction. The generation of reactive organic species of each catalyst has been investigated to the photochemical reduction of the $\left.\left(\mathrm{NH}_{3}-\mathrm{trz}\right)[\mathrm{Fe} \text { (dipic })_{2}\right]$ complex [75]. In a typical process, coumarin used as the ${ }^{\bullet} \mathrm{OH}$-trapping agent, allowing the measurement 
of photoluminescence intensity with an excitation wavelength at $332 \mathrm{~nm}$ are depicted in Fig. 15. The characteristic photoluminescence (PL) emission peak at about $450 \mathrm{~nm}$ of 7hydroxycoumarin (7-OH coumarin) for all catalyst is measured for $60 \mathrm{~min}$ are presented in Table T7. Nanostructured $\mathrm{TiO}_{2}$ offered much higher PL intensity than $\mathrm{SnO}_{2} / \mathrm{TiO}_{2}$ nanocomposites and bare $\mathrm{SnO}_{2}$ nanoparticles. The results revealed that the $\mathrm{TiO}_{2}$ nanoparticles generate more number of hydroxyl radicals on the surface of the catalyst rather than nanocomposites and $\mathrm{SnO}_{2}$ nanoparticles.

\section{Conclusion}

By integrating nano $\mathrm{TiO}_{2}$ and nano $\mathrm{SnO}_{2}$ into a single-step hydrothermal process, a progressive hybrid design was successfully evolved. In comparison to pure $\mathrm{SnO}_{2}$ and $\mathrm{TiO}_{2}$ nanostructures, the $\mathrm{SnO}_{2} / \mathrm{TiO}_{2}$ nanocomposites had significantly improved self-sensitized degradation efficiency under UV radiation. Exceptionally high efficacy could be credited to acceptable contact and suitable energy band alignment cum arrangement of $\mathrm{SnO}_{2}$ and $\mathrm{TiO}_{2}$ phases, which empowered the solid coupling connection. The adsorption capacity of $\left(\mathrm{NH}_{3}-\operatorname{trz}\right)\left[\mathrm{Fe}(\mathrm{dipic})_{2}\right]$ by $\mathrm{SnO}_{2} / \mathrm{TiO}_{2}$ nanocomposites in $\mathrm{H}_{2} \mathrm{O} / \mathrm{DMSO}(70 / 30 \%(\mathrm{v} / \mathrm{v}))$ is higher than that of other solvents mixtures. The photocatalytic reduction of the $\left(\mathrm{NH}_{3}-\mathrm{trz}\right)\left[\mathrm{Fe}(\text { dipic })_{2}\right]$ complex in $\mathrm{H}_{2} \mathrm{O} / \mathrm{Pr}^{\mathrm{i}} \mathrm{OH}$ $(70 / 30 \%(\mathrm{v} / \mathrm{v}))$ gives the best results compared to other solvent mixtures. Interestingly, the photogenerated electron's lifetime was enhanced when it was distributed across the progressive network. The $\mathrm{SnO}_{2} / \mathrm{TiO}_{2}$ nanocomposites acted as electron sinks, causing electrons to separate spatially, and as effective electron mediators, promoting the development of diminished products. The $\mathrm{SnO}_{2} / \mathrm{TiO}_{2}$ nanocomposites can explain light-harvesting ability, prompting improved photon retention in the metal complex. The synergistic effects of these components, together with their incredible light absorption ability, have resulted in a phenomenal improvement in photoreduction density. Coumarin has been used to probe the photocatalytic efficiency of the catalyst by observing 7-OH-coumarin at fluorescence excitation $332 \mathrm{~nm}$ (inner-filtering effect). These findings support efforts to expand this technique to manufacture metal-nanocomposite hybrid nanostructures, permitting mixtures for various metal nanostructures of divalent and trivalent cations, potentially opening up a wide range of applications due to the exceptionally tailored characteristics.

\section{Acknowledgments}

The authors thank to Central Instrumentation Facility (CIF), Pondicherry University for providing an instrumental facility.

\section{Supplementary Material}

Full crystallographic data for the structural analysis have been deposited with the Cambridge Crystallographic Data Center, CCDC No. 2039804. This data can be obtained free of charge 
via www.ccdc.cam.ac.uk or from Cambridge Crystallographic Data Center,12 Union Road, Cambridge, CB2,1EZ, UK (fax: +44 (0)1223336033 or email: deposit@ccdc.cam.ac.uk).

Supplementary data of UV-Visible absorption spectrum, photoluminescence, Raman and FTIR spectra of iron(III) complex. Electronic absorption curves with various conditions, together with geometric and Cyclic voltammograms parameters. UV-vis DRS spectra, Photoluminescence spectra and FT-IR spectra of nanocomposites and its bare components. $M$ $H$ loop curve parameters, intensity values of hydroxyl trapping experiments and efficiency data of $\mathrm{Fe}(\mathrm{II})$ formation.

\section{Funding}

KA records his sincere thanks to the Council of Scientific and Industrial Research-HRDG (EMR Division, No. 01(2953)/18/EMR-II/1.5.2018), New Delhi, for financial support through a major research project.

\section{Author Contributions}

D.Venkatesh designed the project, lab work, and write up. S. Pavalmalar contributed characterization and revised manuscript. R.Silambarasan assisted photodegradation experiments. K.Anbalagan supervised the work.

Conflict of interest The authors declare that they have no conflict of interest.

\section{References}

1. Q. Xiang, J. Yu and M. Jaroniec., Chem. Soc. Rev., 41, 782-796 (2012).

2. M. S. Chavali and M. P. Nikolova, SN Applied Science, 1, 607 (2019).

3. Y. Zhang, Z. R. Tang, X. Fu, and Y. J. Xu, ACS Nano, 4, 7303-7314 (2010).

4. L Ge and J Liu. Appl. Catal. B., 105, 289-297 (2011).

5. T. Zhou, M. Lu, Z. Zhang, H. Gong, W. S. Chin, and B. Liu, Adv. Mater., 22, 403-406 (2010).

6. G. Liu, L. Z. Wang, H. G. Yang, H. M. Cheng and G. Q. Lu, J. Mater. Chem., 20, 831-843 (2010).

7. L. Jinlong, J. Shuaiqiang, S. Guozhe, D. Lijuan and L. Boxin, RSC Adv., 7, 34857, (2017).

8. Y. Cao, X. T. Zhang, W. S. Yang, H. Du, Y. B. Bai, T. J. Li and J. N. Yao, Chem.Mater., 12, 3445-3448 (2000).

9. L. Cojocaru, C. Olivier, T. Toupance, E. Sellierb and L. Hirsch, J. Mater. Chem. A, 1, 1378913799 (2013).

10. M. S. Park, G. X. Wang, Y. M. Kang, D. Wexler, S. X. Dou, and H. K. Liu, Angew. Chem. Int. Ed. Engl., 46, 750 (2007).

11. L.Xu, E.M. P. Steinmiller, and S.E. Skrabalak., J. Phys. Chem. C, 116, 871-877 (2012).

12. Z. Liu, D. D.Sun, F.Guo and J.O. Leckie, Nano Lett. 7, 1081-1085 (2007). 
13. F. Gyger, M. Hubner, C. Feldmann, N. Barsan and U. Weimar, Chem. Mater., 22, 48214827(2010).

14. J. Shang, W.Yao, Y.Zhu, N.Wu. Appl. Catal. A, 257, 25-32 (2004).

15. J. Q. Hu, X. L. Ma, N. G. Shang, Z. Y. Xie, N. B. Wong, C. S. Lee and S. T. Lee, J. Phys. Chem. B, 106, 3823-3826 (2002).

16. Y. Tang, D. Wu, S. Chen, F. Zhang, J. Jia and X. Feng, Energy Environ. Sci., 6, 2447 (2013).

17. Z. R. Dai, Z. W. Pan and Z. L.Wang. Solid State Commun., 118, 351 (2001).

18. J. Xu, W. Dong, C. Song, Y. Tang, W. Zhao, Z. Hong and F. Huang, J. Mater. Chem. A, 4, 15698-15704 (2016).

19. M. Li, Y. Hu, S. Xie, Y. Huang, Y. Tong and X. Lu, Chem. Commun., 5, 4341-4343 (2014).

20. X. Chen, B. H. Zhou, S. L. Yang, H.S. Wu, Y. Wu, L. Wu, J. Pan and X. Xiong, RSC Adv., 5, 68953, (2015).

21. C. Shifu, C. Lei, G. Shen and C. Gengyu, Mater. Chem. Phys., 98, 116-120 (2006).

22. X. Xu, X. Li, P. Lin, T. Chen, R. Yuan, Z. Ding, L.Wu, X. Wang, and Z. Li, Chem. Commun., 47, 2538-2540 (2011).

23. C. Enachescu, A. Hauser, J. J. Girerd and M. L. Boillot, ChemPhysChem, 7, 1127-1135 (2006).

24. F.Ghasemi, K.Ghasemi, A.R.Rezvani, M.M.Rosli and I. A.Razak, J. Mol. Struct., 1144, 186-190 (2017).

25. I.P. Pozdnyakov, V.F. Plyusnin, V.P. Grivin and E. Oliveros, J. Photochem. Photobiol. A: Chem., 307, 9-15 (2015).

26. D. Dey, G. Kaur, M. Patra, A.R. Choudhury, N. Kole and B. Biswas, Inorg. Chim. Acta, 421, 335-341 (2014).

27. K. Dankhoffa and B. Weber, Dalton Trans., 48, 15376-15380 (2019).

28. G. G. Bombi, R. Aikebaier, A. Dean, V. B. Di Marco, D. Marton and A.Tapparo, Polyhedron., 28, 327-335 (2009).

29. D.Venkatesh, S.Pavalamalar and K.Anbalagan, J.Mater Sci: Mater Electron., 30, 92459258 (2019).

30. C. K. Lim, Y. Wang and L. Zhang, RSC Adv., 6, 25114-25122 (2016).

31. M.T. Maurette, A.M. Braun and E. Oliveros, Photochemical Technology, Wiley, Chichester-New York-Brisbane-Toronto-Singapore, (1991).

32. M. P. Singh and J. B. Baruah, Polyhedron., 138, 103-108 (2017).

33. D. Moon and J. H. Choi, Acta Crystallogr. Sect. E71, 210-212 (2015).

34. Rafizadeh, B. Mehrabi and V. Amani, Acta Cryst. E62, m1332-m1334 (2006). 
35. G.W. Zhou, A. Q. Wu, M. S Wang, G. C. Guo and J. S. Huang, Acta Cryst., E63, m2463m2464 (2007).

36. K. Nakamoto, fifth ed., Wiley Interscience, New York, (1997).

37. K. R Krishnapriya and M. Kandaswamy, Carbohyd. Res., 345, 2013-2022 (2010).

38. P. Laid, A. Gourdon and J.P. Launay, Inorg. Chem., 34, 5129-5137 (1995).

39. X. Zhang, J. X. Yang, J.Zhang, J. K.Cheng, M. L. Sun, and Y. G. Yao, Inorg. Chem. Commun., 14, 986-989 (2011).

40. Y. Zhang, T. G. Zhan, T. Y. Zhou, Q. Y. Qi, X. N. Xu and X. Zhao, Chem. Commun., 52, 7588-7591 (2016).

41. S. Chakraborty, M. G. Walawalkar, and G. K. Lahiri, J. Chem. Soc., Dalton Trans., 28752883 (2000).

42. J. Cho, S. Jeon, S. A. Wilson, L. V. Liu, E. A. Kang, J. J. Braymer, M. H. Lim, B. Hedman, K. O. Hodgson, J. S. Valentine, E. I. Solomon and W. Nam, Nature, 478, 502-505 (2011).

43. J. Hohenberger, K. Ray and K. Meyer, Nat Commun., 3, 720 (2012).

44. P. M. Bush, J. P.Whitehead, C. C. Pink, E. C. Gramm, J. L. Eglin, S. P.Watton and L. E. Pence, Inorg. Chem., 40, 1871-1877 (2001).

45. I. Ucar, B. Karabulut, A. Bulut and O. Buyukgungor., J. Mol. Struct., 834-836, 336-344 (2007).

46. R. Uhrecky’, Z. P. lková, J. Moncol, M. Koman L. Dlhán`, J. Titiš and R. Boca, Polyhedron, 56, 9-17 (2013).

47. I. Uçar, Ö. Tamer, B. Saribog a and O. Büyükgüngör, Solid State Sci., 15, 7-16 (2013).

48. M. Tabatabaee, F. Abbasi, B. M. Kukovec and N. Nasirizadeh, J. Coord. Chem., 64, 17181728 (2011).

49. C.A. Akinremi, V. B. Oyelude, S. Adewuyi, S. A. Amolegbe and T. Arowolo, J. Macromol. Sci., Part A: Pure Appl. Chem., 50, 435-440 (2013).

50. I. Nemec, R. Herchel, R. Boca, Z. Travnicek, I. Svoboda, H. Fuess and W. Linert., Dalton Trans., 40, 10090-10099 (2011).

51. A. S. Ganeshraja, A. Clara, K. Rajkumar, Y. Wang, Y.Wang, J. Wang and K. Anbalagan., Appl. Surf. Sci., 353, 553-563 (2015).

52. A. Iwaszuk and M. Nolan, J. Mater. Chem. A, 1, 6670-6677 (2013).

53. N. G. Park, M. G. Kang, K. S. Ryu, K. M. Kim, and S. H. Chang, J. Photochem. Photobiol., A, 161, 105-110 (2004).

54. H. C. Yu and P. Shen, J. Eur. Ceram. Soc., 28, 91-99 (2008).

55. M.F. Abdel-Messih, M.A. Ahmed and A.S. E. Sayed, J. Photochem. Photobiol. A Chem., 260, 1-8 (2013). 
56. I. Zardo, S. Conesa-Boj, F. Peiro, J. R. Morante, J. Arbiol, E. Uccelli, G. Abstreiter, Phys. Rev. B, 80, 245324 (2009).

57. C. Pérez León, L. Kador, B. Peng and M. Thelakkat., J. Phys. Chem. B, 17, 8723-8730 (2006).

58. G. Yang, Z. Jiang, H. Shi, T. Xiao, and Z. Yan. J. Mater. Chem., 20, 5301-5309 (2010).

59. Z. Yi, Q. Han, P. Zan, Y. Cheng, Y. Wu and L. Wang, J. Mater. Chem. A, 4, 12850-12857 (2016).

60. J. Tauc, R. Grigorovict and A. Vancu, Phys. Status Solidi, 15, 627-637 (1966).

61. L.Xu, E.M.P. Steinmiller and S.E. Skrabalak., J. Phys. Chem. C, 116, 871-877 (2012).

62. S. Markovic, A. Stankovic, J. Dostanic, L. Veselinovic, L. Manci, S. D. Skapin, G. Dra zic,

I. J.-Castvan, and D. Uskokovic. RSC Adv., 7, 42725-42737 (2017).

63. P.P. Sahay, R.K. Mishra, S.N. Pandey, S. Jha and M. Shamsuddin., Curr. Appl. Phys., 13, 479-486 (2013).

64. M. Borlaf, M.T. Colomer, R. Moreno, and A. D. Andres, J. Am. Ceram. Soc., 98, 338-345 (2015).

65. Z.C. Su and S.J. Xu., Sol. Energy Mater. Sol. Cells, 193, 292-297 (2019).

66. R. S. Varma, N. Thorat, R. Fernandes, D. C. Kothari, N. Patela and A. Miotello., Catal. Sci. Technol., 6, 8428-8440 (2016).

67. L. C. Chen, C. M. Huang, M. C. Hsiao and F. R. Tsai, Chem. Eng. J., 165, 482-489 (2010). 68. S. Liu, J. H. Yang and J. H. Choy, J. Photochem. Photobiol. A: Chem., 179, 75-80 (2006). 69. M. C. León, E. Coronado, M. L.Jordà, C. Desplanches, S. Asthana, H. Wang and J.-F. Létard, Chem. Sci., 2, 1121-1127 (2011).

70. Y.Ren, G. Zhao and Y. Chen, Appl. Surf. Sci., 258, 914-918 (2011).

71. J. B. Asbury, E. Hao, Y. Wang, H. N. Ghosh and T. Lian, J. Phys. Chem. B, 105, 45454557 (2001).

72. N. S. Langeroodi, Z. Farhadravesh and A. D. Khalaji, Green Chem. Lett. Rev., 11, 404-413 (2018).

73. W. Dong, M. Yan, Z. Liu, G. Wu and Y. Li, Sep. Purif. Technol., 53, 183-188 (2007).

74. R. E. Kitson, Anal. Chem., 22, 664-667 (1950).

75. V. Leandri, J.M. Gardner, and M. Jonsson, J. Phys. Chem. C, 123, 6667-6674 (2019). 
Figures

\section{Figure 1}

See image above for figure legend.

\section{Figure 2}

See image above for figure legend.

\section{Figure 3}

See image above for figure legend.

\section{Figure 4}

See image above for figure legend.

\section{Figure 5}

See image above for figure legend.

\section{Figure 6}

See image above for figure legend.

\section{Figure 7}

See image above for figure legend. 


\section{Figure 8}

See image above for figure legend.

\section{Figure 9}

See image above for figure legend.

\section{Figure 10}

See image above for figure legend.

\section{Figure 11}

See image above for figure legend.

\section{Figure 12}

See image above for figure legend.

\section{Figure 13}

See image above for figure legend.

\section{Figure 14}

See image above for figure legend.

\section{Figure 15}

See image above for figure legend. 


\section{Supplementary Files}

This is a list of supplementary files associated with this preprint. Click to download.

- Table.pdf

- SupplementaryInformation.pdf 